Foreign Fighters under International Law and Beyond 
Andrea de Guttry · Francesca Capone Christophe Paulussen

Editors

\section{Foreign Fighters under International Law and Beyond}


Editors

Andrea de Guttry

DIRPOLIS

Scuola Superiore Sant'Anna

Pisa

Italy

Francesca Capone

DIRPOLIS

Scuola Superiore Sant'Anna

Pisa

Italy
Christophe Paulussen

T.M.C. Asser Instituut/ICCT

The Hague

The Netherlands

ISBN 978-94-6265-098-5

ISBN 978-94-6265-099-2 (eBook)

DOI 10.1007/978-94-6265-099-2

Library of Congress Control Number: 2015954346

Published by T.M.C. ASSER PRESS, The Hague, The Netherlands www.asserpress.nl Produced and distributed for T.M.C. ASSER PRESS by Springer-Verlag Berlin Heidelberg

(C) T.M.C. ASSER PRESS and the authors 2016

No part of this work may be reproduced, stored in a retrieval system, or transmitted in any form or by any means, electronic, mechanical, photocopying, microfilming, recording or otherwise, without written permission from the Publisher, with the exception of any material supplied specifically for the purpose of being entered and executed on a computer system, for exclusive use by the purchaser of the work.

The use of general descriptive names, registered names, trademarks, service marks, etc. in this publication does not imply, even in the absence of a specific statement, that such names are exempt from the relevant protective laws and regulations and therefore free for general use.

Printed on acid-free paper

Springer Science+Business Media B.V. Dordrecht is part of Springer Science+Business Media (www.springer.com) 


\section{Foreword}

The main threat to international security in the twentieth century was conflict between States. Two World Wars led to the creation of the United Nations in 1945, a forum established to ensure that disputes between States did not turn into military confrontations. NATO was established shortly after, as the dreams of a stable post-war order were shattered by the reality of the Cold War.

Policy makers today are rapidly adjusting to the idea that the assumptions underpinning security planning in the twentieth century do not apply to an array of transnational threats which have emerged over the past twenty years. Nowhere is this more apparent than in the case of foreign fighters (FFs).

As this publication will highlight, the phenomenon of foreigners joining conflicts thousands of miles from their homes is not new. Thanks to Orwell and Hemingway, many of us are familiar with the example of the international brigades which were formed to fight on behalf of the second Spanish Republic in the 1930s. More recently, FFs went to Afghanistan in the 1980s to fight Soviet occupation. And many outsiders flooded into the Balkans (particularly Bosnia) in the early 1990s to take up arms against the government in Belgrade.

These examples, in particular the latter two, barely attracted our attention at the time. In Europe, many reasoned that the phenomenon was welcome given that 'my enemy's enemy is my friend'. However, in hindsight, it is clear that the conflicts in Bosnia and in Afghanistan were incubators for the problems we face today, when foreign nationals join groups such as al-Shabab and Boko Haram in Africa, and Da'esh and al-Nusra in the Middle East.

A recent report published by the United Nations highlights the scale of the problem. An estimated 25,000 foreign nationals are fighting on behalf of terrorist groups around the world. Many of these are concentrated in Iraq, Syria, Somalia, Nigeria and across North Africa. Half of the world's countries have supplied FFs. Over the past year, the numbers have doubled and there are no signs of this slowing down.

Given the trend, the public is right to be concerned. Further terrorist attacks in European capitals are inevitable, either because individuals feel inspired to copy terrorists' brutality or as foreign terrorist fighters (FTFs) return to their 
homes. Da'esh in particular has proved adept at convincing thousands of gullible European citizens that their interests are best served by taking up arms against some of the world's most tolerant and diverse societies.

This publication offers a number of prescriptions for tackling the FF phenomenon. I do not claim to have all of the answers, but it strikes me that policy makers should be guided in their actions by three watchwords:

\section{Confidence}

By global standards, European societies remain among the most advanced on earth. The fact that the continent represents the world in so many respects, including the diversity of its population, is a fundamental strength. The fact that we host so many thriving Muslim communities is the best possible response to the terrorist narrative suggesting that the West is at war with Islam. We should work with our diaspora communities relentlessly to promote this message;

\section{Caution}

The first duty of any government is to protect its citizens. Understandably there is a debate underway in many European capitals on the changes necessary to ensure that our security apparatus is equipped to deal with the FF phenomenon. For example, the European Parliament is (rightly in my view) considering a Directive on Passenger Name Records to ensure that law enforcement experts have access to potentially crucial data on the movements of FTFs. But in proposing new measures, we should ensure that they comply with the values which have become synonymous with the EU, namely respect for human rights, democracy and the rule of law;

\section{Unity}

EU citizens have been the target of three significant attacks in 2015 (Paris in January and Bardo and then Sousse in Tunisia). These attacks were clearly inspired by terrorist groups which purport to represent Islam. We will inevitably suffer further attacks, not least as FTFs return to their home countries. But I am confident that by working together across the EU to develop a coherent response to the terrorists' message, we will overcome this generational challenge. In doing so, we will need the support of education specialists who can recognise the signs of radicalisation and equip future generations with critical thinking skills; we will need to develop greater expertise in our law enforcement approach, building 
stronger partnerships between police and local communities; and we need a unified diplomatic and humanitarian effort to bring an end to the conflicts which give many terrorist groups their centrifugal force.

This volume provides food for thought in all of these areas. It is well-timed and, I am sure, will become an essential reference text for policy makers.

Gilles de Kerchove EU Counter-Terrorism Coordinator 


\section{Contents}

$1 \quad$ Introduction .................................... 1

Andrea de Guttry, Francesca Capone and Christophe Paulussen

Part I Foreign Fighters: A Multidisciplinary Overview of New Challenges for an Old Phenomenon

2 Foreign Fighters in the Syria and Iraq Conflict: Statistics and Characteristics of a Rapidly Growing Phenomenon ........ 9 Edwin Bakker and Mark Singleton

3 Foreign Fighters Involvement in National and International Wars: A Historical Survey ........................ Marcello Flores

4 Foreign Fighters as a Challenge for International

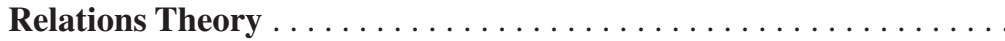
Francesco Strazzari

5 Foreign Fighters: Motivations for Travel to Foreign Conflicts . Ross Frenett and Tanya Silverman

6 The Emerging Role of Social Media in the Recruitment of Foreign Fighters

Gabriel Weimann

7 Analysing the Recruitment and Use of Foreign Men and Women in ISIL through a Gender Perspective. .

Dallin Van Leuven, Dyan Mazurana and Rachel Gordon

8 The Military Impact of Foreign Fighters on the Battlefield:

The Case of the ISIL Fabrizio Coticchia 
Part II The Legal Dimension: The Status of the Foreign Fighters

9 The Status of Foreign Fighters under International Humanitarian Law . . . . . . . . . . . . . . . . . . . . . . . . . . . 141

Emanuele Sommario

10 Foreign Fighters and International Criminal Law . . . . . . . . . . 161 Robert Heinsch

11 Child Soldiers: The Expanding Practice of Minors Recruited to Become Foreign Fighters . . . . . . . . . . . . . . . . . . 187 Francesca Capone

12 Armed Opposition Groups' (and Foreign Fighters')

Abidance by International Human Rights Law:

The Issue of Compliance in Syria and Iraq 205

Daniele Amoroso

Part III Tackling the Phenomenon of Foreign Fighters at the Supranational Level

13 The Obligations under International Law of the Foreign Fighter's State of Nationality or Habitual Residence, State of Transit and State of Destination.

Sandra Krähenmann

14 The Role Played by the UN in Countering the Phenomenon of Foreign Terrorist Fighters Andrea de Guttry

15 States' Prevention and Responses to the Phenomenon of Foreign Fighters Against the Backdrop of International

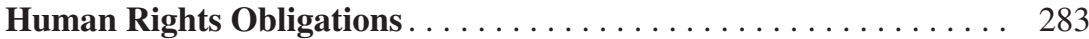
Alex Conte

16 The Regional Answers and Governance Structure for Dealing with Foreign Fighters: The Case of the EU. . . . . . . . . . . . . . . . . . 299 Gilles de Kerchove and Christiane Höhn

17 Collecting and Sharing Intelligence on Foreign Fighters in the EU and its Member States: Existing Tools, Limitations and Opportunities

Matteo E. Bonfanti

18 Towards Effective Regional Responses to the Phenomenon of Foreign Fighters: The OSCE Toolbox Annalisa Creta 
19 The African Union and the Phenomenon of Foreign Fighters in Africa

Linda Darkwa

Part IV Tackling the Phenomenon of Foreign Fighters at the National Level

20 National Responses in Select Western European Countries to the Foreign Fighter Phenomenon

Christophe Paulussen and Eva Entenmann

21 How Western Non-EU States Are Responding to Foreign

Fighters: A Glance at the USA, Canada, Australia, and New Zealand's Laws and Policies. .

Aaron Y. Zelin and Jonathan Prohov

22 MENA Countries' Responses to the Foreign

Fighter Phenomenon.

Daveed Gartenstein-Ross and Bridget Moreng

23 Foreign Fighters and the Deprivation of Nationality:

National Practices and International Law Implications

Laura Van Waas

24 Caught in the Crossfire: The Impact of Foreign Fighters on Internally Displaced Persons, Asylum Seekers and Refugees from Syria and Iraq.

Francesca Vietti and Mike Bisi

25 Concluding Remarks.

Andrea de Guttry, Francesca Capone and Christophe Paulussen

Author Index

Subject Index . 


\section{Abbreviations}

ACBPS Australian Customs and Border Protection Service

ACSRT African Centre for the Study and Research on Terrorism

AFRIPOL African Police Cooperation Organisation

ALA Arab Liberation Army

ANZCTC Australia-New Zealand Counter-Terrorism Committee

AP I

Additional Protocol I to the 1949 Geneva Conventions

AP II

Additional Protocol II to the 1949 Geneva Conventions

API

Advanced Passenger Information

AQAP

Al-Qaeda in the Arab Peninsula

AQIM

Al-Qaeda in the Islamic Maghreb

ASIO

AST

Australian Security Intelligence Organisation

ATU

Ansar al-Sharia in Tunisia

AU

Action against Terrorism Unit

AWB

African Union

BPC

Afrikaner Resistance Movement

CISSA Committee of Intelligence and Security Services of Africa

CODEXTER Council of Europe Committee of Experts on Terrorism

$\mathrm{CoE} \quad$ Council of Europe

CRC Convention on the Rights of the Child

CSCC Center for Strategic Counterterrorism Communications

CSIS Canadian Security Intelligence Service

CTC Counter-Terrorism Committee

CTED Counter-Terrorism Committee Executive Directorate

CTITF Counter-Terrorism Implementation Task Force

CVE Countering Violent Extremism

DCC Dutch Criminal Code

DHS Department of Homeland Security

ECHR European Convention on Human Rights

ECOWAS Economic Community of West African States 


\begin{tabular}{|c|c|}
\hline ECRIS & European Criminal Records Information System \\
\hline EEAS & European External Action Service \\
\hline ENP & European Neighbourhood Policy \\
\hline EU & European Union \\
\hline EUMS & European Union Military Staff \\
\hline FF & Foreign Fighter \\
\hline FRY & Federal Republic of Yugoslavia \\
\hline FSA & Free Syrian Army \\
\hline FTF & Foreign Terrorist Fighter \\
\hline FTO & Foreign Terrorist Organisation \\
\hline $\mathrm{GC}$ & Geneva Convention \\
\hline GCCS & Global Center on Cooperative Security \\
\hline GCTF & Global Counterterrorism Forum \\
\hline IAC & International Armed Conflict \\
\hline ICC & International Criminal Court \\
\hline ICCPR & International Covenant on Civil and Political Rights \\
\hline ICCT & International Centre for Counter-Terrorism-The Hague \\
\hline ICL & International Criminal Law \\
\hline ICSR & $\begin{array}{l}\text { International Centre for the Study of Radicalisation and Political } \\
\text { Violence }\end{array}$ \\
\hline ICTR & International Criminal Tribunal for Rwanda \\
\hline ICTY & International Criminal Tribunal for the Former Yugoslavia \\
\hline IDPs & Internally Displaced Persons \\
\hline IHL & International Humanitarian Law \\
\hline IHRL & International Human Rights Law \\
\hline ILC & International Law Commission \\
\hline IR & International Relations \\
\hline IS & Islamic State \\
\hline ISIL & Islamic State of Iraq and the Levant \\
\hline ISIS & Islamic State of Iraq and Syria \\
\hline JHA & Justice and Home Affairs \\
\hline KLA & Kosovo Liberation Army \\
\hline MENA & Middle East and North Africa \\
\hline MLA & Mutual Legal Assistance \\
\hline MLAT & Mutual Legal Assistance Treaties \\
\hline MUJAO & Movement for the Oneness of the Jihad in Africa \\
\hline NCTC & National Counterterrorism Center \\
\hline NGO & Non-Governmental Organisation \\
\hline NIAC & Non-International Armed Conflict \\
\hline NSAG & Non-State Armed Group \\
\hline NZSIS & New Zealand Security Intelligence Service \\
\hline OHCHR & Office of the High Commissioner for Human Rights \\
\hline OSCE & Organization for Security and Co-operation in Europe \\
\hline PIRA & Provisional Irish Republican Army \\
\hline PNR & Passenger Name Record \\
\hline
\end{tabular}




$\begin{array}{ll}\text { POW } & \text { Prisoner of War } \\ \text { PTSD } & \text { Post-Traumatic Stress Disorder } \\ \text { RAN } & \text { Radicalisation Awareness Network } \\ \text { SCSL } & \text { Special Court for Sierra Leone } \\ \text { SIS } & \text { Schengen Information System } \\ \text { SNTT } & \text { Say No to Terror } \\ \text { SSCAT } & \text { Syria Strategic Communications Advisory Team } \\ \text { STL } & \text { Special Tribunal for Lebanon } \\ \text { TEU } & \text { Treaty on European Union } \\ \text { TFEU } & \text { Treaty on the Functioning of the European Union } \\ \text { TIDE } & \text { Terrorist Identities Datamart Environment } \\ \text { UK } & \text { United Kingdom } \\ \text { UN } & \text { United Nations } \\ \text { UNAMI } & \text { United Nations Assistance Mission for Iraq } \\ \text { UNGA } & \text { United Nations General Assembly } \\ \text { UNICRI } & \text { United Nations Interregional Crime and Justice Research Institute } \\ \text { UNODC } & \text { UN Office on Drugs and Crime } \\ \text { UNSC } & \text { United Nations Security Council } \\ \text { UNSG } & \text { United Nations Secretary-General } \\ \text { USAID/OTI } & \text { US Agency for International Development's Office of Transition } \\ & \text { Initiatives } \\ \text { VBIED } & \text { Vehicle-Borne Improvised Explosive Device }\end{array}$




\section{Editors and Contributors}

\section{About the Editors}

Andrea de Guttry is full Professor of Public International Law at the Scuola Superiore Sant'Anna, Pisa, Italy. He is also the Deputy Rector of the Scuola and Director of the DIRPOLIS (Law, Politics and Development) Institute. He was the founder, in 1995, of the International Training Programme for Conflict Management in the framework of which more than 600 training courses have been designed and organised targeting the civilian personnel working in international field operations. One of his most recent books, International Disaster Response Law with G. Venturini and M. Gestri, was published by Springer/T.M.C. Asser Press in 2012.

Francesca Capone is a Research Fellow in Public International Law at the Scuola Superiore Sant'Anna where she serves also as the Didactic Coordinator of the Master in Human Rights and Conflict Management. She holds a Joint Ph.D. in Public International Law from the Scuola Superiore Sant'Anna and Tilburg University. From June 2012 to September 2013 she was a Research Fellow at the British Institute of International and Comparative Law and she co-authored a report on Education and the Law of Reparations in Insecurity and Armed Conflict. Her research interests focus on children's and victims' rights, in particular the right to a remedy and reparation.

Christophe Paulussen is a senior researcher international humanitarian law/ international criminal law and coordinator of the Public International Law cluster at the T.M.C. Asser Instituut, coordinator of the inter-faculty research platform 'International Humanitarian and Criminal Law Platform' and research fellow at the International Centre for Counter-Terrorism (ICCT)_-The Hague. Christophe's areas of interest are international humanitarian law, international criminal law, in particular the law of the international criminal(ised) tribunals, and counter-terrorism \& human rights, in particular the issue of foreign fighters. He has published in all these areas. 


\section{Contributors}

Daniele Amoroso is Lecturer in International Law at the Department of Law of the University of Naples 'Federico II'. He is member of the Editorial Committee of the Italian Yearbook of International Law and national reporter for the 'International Law in Domestic Courts' (ILDC) database. His areas of interest include the relationship between municipal law and international law, the law of self-determination and human rights law.

Edwin Bakker is director of the Centre for Terrorism and Counter-terrorism of Leiden University and fellow of the International Centre for Counter-TerrorismThe Hague. His areas of research interest include radicalization, jihadist terrorism in Europe and the phenomenon of foreign fighters. He recently published 'Terrorism and Counterterrorism Studies. Comparing Theory and Practice' with Leiden University Press. This handbook is linked to a Coursera Massive Open Online Course which has attracted over 100,000 participants. Prof. Bakker is involved in several international research projects on lone actor terrorism and religiously inspired terrorism.

Mike Bisi acquired expertise on migration, refugee, asylum and demographic issues as consultant at the UNHCR, researcher at the United Nations and legal officer at the International Labour Organization. He drafted comparative reports on asylum and migration systems for national parliamentary commissions before becoming the deputy Co-ordinator at the Inter-Governmental Consultations on Migration, Refugee and Asylum Policies in Europe, North America and Australia. Mike set up the Temporary Desk on Iraq, which facilitated practical cooperation and was extended to the Afghan, Russian Federation and Somali caseloads. As an independent expert, Mike trains government officials and students in international migration and refugee law.

Matteo E. Bonfanti works as Research Fellow at the Scuola Superiore Sant'Anna di Pisa. His current research focuses on the legal and fundamental rights issues raised by targeted initiatives adopted by the EU and its Member States to foster their internal security. These include new solutions to enhance CBRNe preparedness and response, policing and intelligence cooperation, the gathering and sharing of Internet-based and social media intelligence, and the development and use of new or emerging technologies for security purposes. Matteo is also an expert on privacy and data protection, and holds a Ph.D. in International Fundamental Rights Law.

Alex Conte is a Reader in Human Rights at Sussex Law School, with research interests and teaching focused on global security and human rights, detention and fair trial and the interface between international human rights and humanitarian law. He is Director of the Sussex Centre for Human Rights Research. Alex was the 2004 New Zealand Law Foundation International Research Fellow. Recent publications include: 'The Responsibility to Protect and Syria' in The War Report 2013 (OUP, 2014); and 'Human Rights Beyond Borders: A new era in human rights 
accountability for transnational counter-terrorism operations?' (2012) Journal of Conflict and Security Law.

Fabrizio Coticchia Ph.D. is Assistant Professor of Political Science at the University of Genoa. He has been Jean Monnet Fellow at the European University Institute and Research Fellow in international relations at the Scuola Superiore Sant'Anna (Pisa). His fields of research are contemporary warfare, strategic culture, public opinion and military operations, Italian and European defence policy, development and cooperation. Recent books include: 'Italian Military Operations Abroad: Just Don't Call it War', with P. Ignazi and G. Giacomello (Palgrave 2012); and 'Adapt, Improvise, Overcome? The Transformation of Italian Armed Forces in Comparative Perspective', with F.N. Moro (Ashgate 2015).

Annalisa Creta Ph.D. is a research fellow in International Law at the Scuola Superiore Sant'Anna of Pisa where she focuses on issues related to civilian crisis management, with a particular emphasis on training related matters. Her main interests lie in Human Rights Law, the International Law on the Use of Force, Collective Security Law and International Disaster Response law, and she is the author of several publications on the above topics.

Linda Darkwa is a Research Fellow at the Legon Centre for International Affairs and Diplomacy of the University of Ghana, Legon where she teaches courses in international law and international humanitarian law. A peace and security analyst with a focus on Africa, her research interests are in the areas of peace and security with a particular focus on the implications of global security paradigms on regional and local processes of governance, human rights, development, and security.

Gilles de Kerchove was appointed EU Counter-Terrorism Coordinator on 19 September 2007. In this function, he coordinates the work of the European Union in the field of counter-terrorism, maintains an overview of all the instruments at the Union's disposal, closely monitors the implementation of the EU counter-terrorism strategy and fosters better communication between the EU and third countries to ensure that the Union plays an active role in the fight against terrorism. He is also a European law professor at the Catholic University of Louvain, the Free University of Brussels and at the Université Saint Louis-Brussels.

Eva Entenmann is Programme Manager at the International Centre for CounterTerrorism-The Hague (ICCT). In this capacity she is responsible for the acquisition, implementation and monitoring of various activities that are at the intersection of preventative and legal aspects of (counter-) terrorism, including projects related to the rule of law, countering violent extremism, civil society engagement, involving victims in countering terrorism, and criminal justice sector responses to terrorism. She has published on a number of topics including the phenomenon of foreign fighters.

Marcello Flores teaches Comparative History and History of Human Rights at the University of Siena, where he coordinates the European Master in Human Rights and Genocide Studies. He is scientific director of the 'Istituto per la Storia del 
Movimento di Liberazione in Italia', one of the editors of the 'Storia della Shoah' (Turin, 6 voll.) and of 'Diritti umani. La cultura dei diritti e la dignità della persona nell'epoca della globalizzazione' (Turin, 6 voll.) His main research interests are the history of totalitarianisms, of genocides, and of human rights. His most recent book is 'Traditori. Una storia politica e culturale', (il Mulino, Bologna 2015).

Ross Frenett is the Founding Director of Moonshot CVE, a specialist CVE focused organisation which aims to develop emerging methodologies to counter violent extremism. Ross previously served as Director of the Against Violent Extremism (AVE) network, a global network of former extremists and survivors of violent extremism seeded by Google Ideas and managed by the Institute for Strategic Dialogue. Throughout his career Ross has interviewed hundreds of former members of extremist groups and is a regular media commentator on the subject of extremism. He holds a Masters in Terrorism Security and Society from King's College London and a B.A. from University College Cork.

Daveed Gartenstein-Ross's professional and academic work focus on the growing challenge posed by violent non-state actors. He is a senior fellow at the Foundation for Defense of Democracies, the chief executive officer of the consulting firm Valens Global, and an adjunct assistant professor in Georgetown University's security studies program. Gartenstein-Ross couples academic credentials across multiple disciplines with extensive experience working for governmental and non-governmental clients. He is the author or volume editor of nineteen books and monographs, and has published widely in the popular and academic press.

Rachel Gordon is a Researcher at the Feinstein International Center at Tufts University, Boston. Her research interests include gendered participation in and impacts of violence, urban crises and marginalization, and the politics of aid. Rachel's current work studies the links between livelihoods, service delivery and state legitimacy in conflict-affected countries in Africa, the Middle East and South Asia, as part of the Secure Livelihoods Research Consortium at the Overseas Development Institute (ODI) in London. She holds Master's degrees in international affairs, specialising in gender and human security, and urban studies and planning.

Robert Heinsch LL.M. is Associate Professor of Public International Law at the Grotius Centre for International Legal Studies of Leiden University, and the Director of its regular LL.M. Programme in Public International Law. He is also the Director of the Kalshoven-Gieskes Forum on International Humanitarian Law and its law clinic. He is rapporteur and co-founder of the ILA study group on the 'Challenges from 21st Century Warfare'. Previously, he has worked as the Federal Dissemination Officer of the Red Cross in Berlin, and as a Legal Officer in the Trial Chamber of the International Criminal Court in The Hague.

Christiane Höhn has been adviser to the European Union Counter-Terrorism Coordinator (since 2010). Her previous assignments at the EU included non-proliferation, transatlantic relations as well as counter-terrorism and international law. She holds the German State Examinations in law, an LL.M. (Harvard Law School) and 
a Ph.D. in international law (Heidelberg). Prior to joining the EU in 2004, she was a researcher at the Max Planck Institute for International Law and an Affiliate at the Center for Public Leadership, Harvard Kennedy School. She has published a book and several articles.

Sandra Krähenmann is a research fellow at the Geneva Academy of International Humanitarian Law and Human Rights for the rule of law in armed conflicts initiative and a series of projects related to foreign fighters and other armed non-state actors. Sandra's main research interests are international humanitarian law, in particular its interplay with human rights law, and counter-terrorism and human rights.

Dyan Mazurana Ph.D. is Associate Research Professor at the Fletcher School of Law and Diplomacy, Senior Fellow at the World Peace Foundation and Research Director at the Feinstein International Center, Tufts University. Mazurana's areas of interest include women, children and armed conflict, documenting serious crimes committed during conflict, remedy and reparation, and research methods in situations of armed conflict. Her latest books include 'Research Methods in Conflict Settings: A View from Below' (Cambridge University Press, 2014) with K. Jacobsen and L. Gale; 'After the Taliban: Life and Security in Rural Afghanistan' (Rowman and Littlefield, 2008) with N. Nojumi and E. Stites.

Bridget Moreng is an analyst at Valens Global focusing on militant organisations in the Middle East and North Africa. Her recent work has focused on the ISIS insurgency in Iraq, and the organisation's move towards international expansion. She has also extensively studied the competition between ISIS and al-Qaeda. Bridget's work has been published in several widely-read media outlets including 'Foreign Affairs', and 'Politico'. Bridget graduated from the University of Colorado at Boulder with dual degrees in international affairs and psychology.

Jonathan Prohov is a Master of Arts in Nonproliferation and Terrorism Studies candidate at the Middlebury Institute of International Studies at Monterey, where he is also a graduate research assistant at the Monterey Terrorism and Research Education Program (MonTREP). Previously he was a research assistant for the Stein Program on Counterterrorism and Intelligence at the Washington Institute for Near East Policy.

Tanya Silverman is a Coordinator at the Institute for Strategic Dialogue (ISD) managing the Against Violent Extremism (AVE) network and counter-narrative projects, in partnership with grassroots and social media companies. As part of this role, encompassing localities ranging from the US to Indonesia, she also plans and implements training workshops for grassroots CVE organisations. Previously she researched new approaches to counter-radicalisation, playing a key role in ISD's policy programmes. Her areas of interest include foreign fighters, the role of education, IHR, visual arts, and counter-narratives. Currently she sits on the UK's Challenge Panel and in the Syria Advisory Committee.

Mark Singleton is Director of the International Centre for Counter Terrorism-The Hague (ICCT). A career diplomat with over 27 years' experience in foreign affairs, 
development cooperation and security, Mark has worked in the Middle East, Afghanistan, East and West Africa, Georgia and Europe in a variety of multilateral, bilateral and non-governmental organisations, in both advisory and senior management posts. Before joining the ICCT, Mark was Acting Head of Mission of the Office of the Quartet Representative in Jerusalem, where he led an international team of over 60 staff to strengthen the Palestinian economy, as part of the Middle East Peace Process.

Emanuele Sommario is Assistant Professor of Public International Law at the Scuola Superiore Sant'Anna of Pisa. His main research interests lie in Human Rights Law, International Humanitarian Law, and International Disaster Law. Emanuele is one of the coordinators of the 'International Disaster Law Project' (www.disasterlaw.sssup.it) and a lecturer and consultant within the EU Civil Protection Mechanism Training Initiative.

Francesco Strazzari is Associate Professor of International Relations at the Scuola Superiore Sant'Anna (Pisa) and adjunct research professor at NUPI (Norwegian Institute of International Affairs, Oslo), where he contributes to the activities of the Consortium for Research on Terrorism and International Crime. He specialises in peace and conflict studies, European security and organised crime. His books and articles focus on geopolitical reconfigurations along Europe's borders, with specific attention to extralegal economies in the Sahel, in the Middle East and in the Balkans.

Dallin Van Leuven is a recent graduate of The Fletcher School of Law and Diplomacy at Tufts University, earning his M.A. and specialising in rule of law, human security, and gender issues. A native of the State of Idaho, Dallin's interests have taken him to live and work in Europe, the Middle East, and West Africa with a variety of local and international organisations.

Laura Van Waas is a Co-Director of the Institute on Statelessness and Inclusion, an independent non-profit organisation committed to promoting the human rights of stateless persons and fostering inclusion, to ultimately end statelessness. She is also a part-time Assistant Professor at Tilburg Law School in the Netherlands. Her Ph.D. manuscript, 'Nationality Matters' (Intersentia, 2008), is widely used as a reference for understanding international statelessness law by researchers and practitioners all over the world. In over a decade of working on statelessness, Laura has carried out a wide array of research and teaching projects, both within academia and for the United Nations High Commissioner for Refugees and other actors.

Francesca Vietti currently serves as Research Assistant at the Scuola Superiore Sant'Anna in Pisa where she investigates on issues related to security, human rights, human mobility and forced migrations. In 2012 and 2013 she has worked as Field Officer in Sicily and Lampedusa for the Italian Red Cross in the framework of the Praesidium Project. In her previous jobs, Francesca acquired expertise on trafficking in human beings, human security, smuggling of migrants both in the Mediterranean and at the southern Mexican border, and on the social and health-related aspects of forced migrations. 
Gabriel Weimann is a Full Professor of Communication at the Department of Communication at Haifa University, Israel. His research interests include the study of media effects, political campaigns, persuasion and influence, modern terrorism and the mass media, and online terrorism. He has published nine books including 'The Theater of Terror'; 'Terror on the Internet'; 'Freedom and Terror'; and 'Terrorism in Cyberspace: The Next Generation'. His papers and research reports, more than 180 publications, have been published in scientific journals and books. He has received numerous grants and awards from international foundations and has been a Visiting Professor at various universities.

Aaron Y. Zelin is the Richard Borow Fellow at the Washington Institute for Near East Policy and Rena and Sami David Fellow at the International Centre for the Study of Radicalisation and Political Violence. He is also a Ph.D. candidate at King's College London where his dissertation is on the history of the Tunisian jihadi movement. Zelin is the founder of the widely acclaimed and cited website Jihadology.net, which is a clearinghouse for Sunni jihadi primary source material, analysis, as well as a translation service. 